DOI 10.15290/pss.2018.34.10

\author{
Michae Kurcwald
}

Uniwersytet Jagielloński

\title{
W CIENIU CZY NA PIEDESTALE? DJ W KULTURZE „FREE TEKNO” A DYSKURS MUZYKI „LUDOWEJ”
}

W 1997 roku w „Studiach Socjologicznych” ukazał się tekst Tomasza Szlendaka Techno-dzieci ery industrialnej portretujący fenomen tak zwanej technomanii [Szlendak, 1997]. Autor opisywał imprezy techno ${ }^{1}$ czerpiąc swoją wiedzę z artykułów prasowych oraz prowadzonej przez kilka lat obserwacji uczestniczącej. Rodzaj mediów, z których pochodziły wspomniane teksty z pewnością wpłynął na kształt pracy.

Sarah Thornton, która podobnie jak Szlendak, badała kultury klubowe, wprowadziła podział na: (1) media masowe, (2) media niszowe, (3) mikromedia [Thornton 2013: 188-243]. Teksty, do których odnosił się Szlendak można zaliczyć przede wszystkim do pierwszej kategorii. Mediami masowymi Thornton nazwała te profesjonalne, o ogólnokrajowym zasięgu, skierowane do szerokiego odbiorcy. Termin „media niszowe”, jak sama nazwa wskazuje, opisuje te powiązane z konkretnymi ruchami, prądami

1 W latach dziewięćdziesiątych terminu „techno” używano w nieco innym, znacznie szerszym znaczeniu niż dzisiaj. Odnosił się on do nieomal wszystkich podgatunków elektronicznej muzyki tanecznej, z których niektóre powstawały jeszcze w połowie lat osiemdziesiątych. Szlendak [1997: 126] wymienia style takie jak: hard house, trip-hop, drum'n'bass oraz trance, traktując je jako podgatunki techno. Podobnie, w jednym z pierwszych programów telewizyjnych dotyczących kultury klubowej w Polsce, wyemitowanych 19 maja 1995 roku w Programie Drugim Telewizji Polskiej, można było usłyszeć wypowiedzi krakowskich DJ-ów, opisujących kolejno: breakbeat, jungle, drum and bass, hardstep, artcore, happy hardcore jako podgatunki techno (https://youtu.be/hlupGH8aLXU, [28.07.2017]). Współcześnie uznaje się je raczej za osobne gatunki muzyczne lub za podgatunki nie mające nic wspólnego $\mathrm{z}$ wąsko rozumianym techno. Zmiany w terminologii dotyczą również świata anglojęzycznego. W popularnym internetowym przewodniku po gatunkach muzyki elektronicznej noszącym nazwę Ishkur's Guide to Electronic Music 2.5 napisanym przez Kennetha Taylora, przy gatunku „techno dance” w zakładce „house” można przeczytać, że w pewnym momencie nieomal cała nowa taneczna muzyka elektroniczna była nazywana „techno". Autor ubolewa nad faktem, że wiele osób wciąż kojarzy techno z nieco kiczowatymi, popularnymi przebojami utrzymanymi w estetyce bliskiej dance, http://techno.org/electronic-music-guid, [29.07.2017]). Terminologia używana przez Szlendaka może się zatem wydawać z dzisiejszego punktu widzenia nieco dziwaczna, ale $\mathrm{w}$ żadnym przypadku nie wynika to z muzycznej ignorancji autora. 
czy też gatunkami muzycznymi. Za przykład może posłużyć „The Face” związany z londyńską sceną muzyki new romantic oraz new wave. Media niszowe cechuje spora, choć oczywiście mniejsza niż w wypadku mediów masowych, grupa odbiorców oraz profesjonalizm. Mikromedia to z kolei oddolne, $z$ reguły nieprofesjonalne fanziny, e-ziny czy nawet ulotki i plakaty, wydawane własnym nakładem przez osoby ściśle związane $z$ danym nurtem muzycznym.

W tekście Szlendaka wykorzystano artykuły opublikowane w Magazynie „Gazety Wyborczej”, „Tygodniku Powszechnym”, „Polityce”, „Playboyu” oraz "Machinie” [Imbierowicz 1996, Leszczyński 1996, Marshall 1996, Peach 1997, Podgórska 1997, Smuga 1996, Sarnowicz 1996]. Pierwszy z wymienionych funkcjonował jako cotygodniowy dodatek do wydawanej codziennie „Gazety Wyborczej”. Kolejne dwie pozycje odnoszą się do ogólnopolskich, popularnych tygodników opinii. „Playboy” jest miesięcznikiem erotycznym, publicystycznym i life stylowym, skierowanym przede wszystkim do mężczyzn, niemającym zbyt wiele wspólnego ze sceną tanecznej muzyki elektronicznej. Wśród wymienionych tytułów, do kategorii mediów niszowych najbardziej zbliża się „Machina”, będąca miesięcznikiem poświęconym muzyce. Mimo to, trudno uznać żeby się do nich w pełni zaliczała ze względu na to, że jest ogólnym czasopismem muzycznym, niezwiązanym z konkretną sceną czy gatunkiem.

Wybór takich, a nie innych tekstów, które posłużyły jako źródło wiedzy na temat imprez techno, wpłynął na stereotypowość opisu. Media skierowane do szerokiego odbiorcy z konieczności muszą działać opierając się na założeniu, że czytelnika trzeba dopiero wprowadzić w temat, a co za tym idzie, upraszczać przedstawianą rzeczywistość. Komplikowanie i pokazywanie bardziej zniuansowanego obrazu wiązałoby się ze zbyt dużym i trudnym do przyswojenia zagęszczeniem informacji. Można się jedynie domyślać, że w czasach, kiedy omawiany tekst powstawał, nie było możliwości łatwego dotarcia do innego rodzaju źródeł informacji. Ówczesny badacz nie miał zatem zbyt wielkiego wyboru.

\section{Ponowoczesność, indywidualizm, communitas}

Szlendak, mimo prowadzenia obserwacji uczestniczącej, wydaje się być mało krytyczny w stosunku do informacji zawartych w artykułach prasowych. Charakteryzuje on „technomanię” jako zjawisko na wskroś ponowoczesne, cechujące się między innymi: rozbuchanym konsumpcjonizmem, nieliczeniem się z kosztami, afirmacją kapitalizmu i hedonizmu, 
apolitycznością, brakiem ideologii ${ }^{2}$, wymieszaniem kiczu i awangardy, heteronomicznością, naciskiem na modę i eklektycznym stylem ubierania się, ulotnością, efemerycznością, niestałością.

Wymienione cechy pokrywają się nieomal w stu procentach $\mathrm{z}$ listą charakteryzującą „wrażliwość ponowoczesną”, zaprezentowaną przez Davida Muggletona [por. 2004: 69, Szlendak 1997]. Zbieżność ta jest prawdopodobnie nieprzypadkowa. Okres szczytowej popularności techno przypadł na czasy bezpośrednio po upadku Muru Berlińskiego i rozpadzie ZSRR. Był to moment historycznego zwycięstwa kapitalizmu i liberalnej demokracji, który skłonił Francisa Fukuyamę [1991] do ogłoszenia końca historii. Dziennikarze, zwłaszcza ci z dawnego Bloku Wschodniego, chętnie łączyli nową muzykę z Zachodu z niedawnymi przemianami ustrojowymi, historycznymi i kulturowymi.

Nie dziwi więc, że w analizie fenomenu techno, traktowanego niczym awangarda przyszłości, Szlendak [1997] porusza kwestię indywidualizmu. Imprezy techno opisywane są $\mathrm{w}$ kategoriach przeżycia jednostkowego. Wspólnota, która powstaje w trakcie technoparty jest oparta jedynie na wspólnym doświadczeniu. Jest ulotna, ponieważ kończy się w momencie zakończenia imprezy. Szlendak przyrównuje tymczasową wspólnotę uczestników technoparty do communitas raczej niż do community.

Mimo mistycznego wręcz, kolektywnego tanecznego uniesienia, w zindywidualizowanym nowoczesnym świecie wspólnoty musiały mieć charakter tymczasowy. Być może właśnie dzięki przemijalności osiągnięcie silnego poczucia wspólnoty było dla nastawionych indywidualistycznie jednostek możliwe. To co działo się w klubie zostawało w klubie. Indywidualny status jednostki pozostawał niezagrożony. Proces utraty statusów był krótkotrwały i odwracalny. Stąd też zastosowanie w tekście Turnerowskiej kategorii liminoidalności. Szlendak nie twierdzi zatem, że „techno rytuał” ma zdolność do głębokiej, trwałej transformacji uczestników. Tak czy inaczej, w trakcie „technoparty” pozycje i statusy zostawały jednak czasowo zawieszone. Rzecz jasna, profesjonalna obsługa klubów ze swoich ról nie wychodziła. Biorąc pod uwagę samych imprezowiczów obecnych na parkiecie, porzucenie statusów powodowało, że nie występowały między nimi szczególne różnice. Szlendak wspomina, że jedyną postacią zyskującą pewne wyróżnienie był DJ, ale wątku tego specjalnie nie rozwija.

Szlendak wspomina co prawda później o zaangażowanym ideologicznie nowym ruchu społecznym znanym pod nazwą „zippies”, związanym z taneczną muzyką elektroniczną, ale zauważa, że odłam ten jest raczej niszowy i do tego zupełnie nieobecny w Polsce [Szlendak 1997: 125]. 


\section{Techno jako muzyka ludowa (folk music)}

Obraz muzyki techno, jaki wyłania się z tekstów prasowych, zdaje się potwierdzać wniosek Simona Fritha, sugerującego że muzyka rave ${ }^{3}$ najlepiej daje się opisać za pomocą kategorii funkcjonujących w ramach dyskursu muzyki ludowej. Oczywiście nie chodzi mu tutaj o wiejski folklor. Frith stworzył na podstawie koncepcji światów sztuki Howarda S. Beckera i socjologii sztuki Pierre’a Bourdieu teorię, w świetle której można wyróżnić trzy najważniejsze typy praktyk dyskursywnych skoncentrowanych wokół muzyki. Należy je traktować jako weberowskie typy idealne, ponieważ żadna scena muzyczna, prąd, ani gatunek nie da się jednoznacznie opisać za pomocą wyłącznie jednego $\mathrm{z}$ nich. Za każdym razem będziemy mieli do czynienia $\mathrm{z}$ wymieszaniem wszystkich dyskursów. Różnice dotyczyć będą jedynie proporcji między nimi. Typy obejmują:

1) dyskurs artystyczny - powstały w dziewiętnastowiecznym, burżuazyjnym świecie muzyki poważnej, ściśle zhierarchizowany, nakierowany na doświadczenie transcendentne (przy czym transcendencja nie odnosi się do żadnego wyobrażonego świata społecznego, lecz do wymiaru pozaspołecznego), oparty na idei odbioru wykorzystującego wiedzę muzyczną, w warunkach ciszy i skupienia, najlepiej nieruchomo bez udziału ciała;

2) dyskurs muzyki ludowej - cechujący się brakiem rozdziału między sztuką i życiem, zacieraniem granic między wykonawcami i uczestnikami, posiadający starannie wypracowane, niepisane zasady regu-

3 „Rave” to termin, używany współcześnie często w odniesieniu do muzyki oraz kultury związanej z taneczną muzyką elektroniczną, stanowiącej do pewnego stopnia kontynuację brytyjskiego fenomenu imprez acid house. Obejmuje on organizowanie nie zawsze legalnych, otwartych imprez w opuszczonych budynkach lub w trudno dostępnych miejscach pod gołym niebem. Koniec rave'u (a przynajmniej jego pierwszej fali) datuje się na 1994 rok, kiedy w Wielkiej Brytanii uchwalono słynny Criminal Justice and Public Order Act, powszechnie znany jako „ustawa antyrave'owa”. Akt ten zapoczątkował etap „postrave”. Zakazywał spontanicznego organizowania wydarzeń muzycznych, posługując się dość osobliwą definicją muzyki. Ustawodawca zamieścił w tekście aktu zapis, według którego muzyka to nic innego, jak „sukcesywne emitowanie powtarzalnych beatów” (w oryginale: "Music' includes sounds wholly or predominantly characterised by the emission of a succession of repetitive beats", za: http://www.legislation.gov.uk/ukpga/1994/33/contents, [29.07.2017]). Ustawa przewidująca kary pozbawienia wolności oraz konfiskaty sprzętu stanowiła poważny cios dla powstającej sceny tanecznej muzyki elektronicznej, wywołując dwojakie reakcje: z jednej strony "oswojenie" zjawiska i rozwój klubów, z drugiej - próby kontynuacji działań w formie „nieoswojonej” i organizowanie tak zwanych free parties [Collin 2006]. Dla Szlendaka „rave” i „technoparty” są $\mathrm{w}$ zasadzie terminami wymiennymi. Imprezy organizowane na wolnym powietrzu, w miejscach do tego formalnie nieprzeznaczonych, nazywa „orbital rave” lub po prostu „orbital” (choć należy tutaj zaznaczyć, że autor nie zawsze zachowuje konsekwencję w nazewnictwie), [Szlendak 1997: 113]. 
lujące „spontaniczność" i „naturalność”" , świadomie sprzeciwiający się wszelkiemu splendorowi, z kanonem oceny w mniejszym stopniu opartym na wiedzy, nakierowanym na doświadczenie różne od codziennego, lecz niekoniecznie transcendentne (jeżeli są odniesienia do transcendencji, to dotyczy ona przeniesienia się w inny wymiar społeczny);

3) dyskurs muzyki komercyjnej/masowej, którego wartości i kryteria oceny zorganizowane są wokół przemysłu muzycznego, podkreślającego splendor, kosztowność, wysokość sprzedaży, a także gwiazdorski status wykonawcy mającego znacznie wyższą pozycję niż odbiorca; transcendencja zostaje tu zrutynizowana zamieniając się w „fun”, a więc zabawę zintegrowaną z cyklem pracy i odpoczynku [Frith 2011: 45-47, 287, 289, 374].

Technoparty opisywane przez Szlendaka można zatem, przy odrobinie dobrej woli, scharakteryzować w odniesieniu do dyskursu ludowego. Brak rozdziału między sztuką i życiem w przypadku technoparty nie jest co prawda specjalnie oczywisty, ale nie znaczy to, że nie istnieje. Szlendak pisze, że technoparty są szczególnie popularne wśród osób na co dzień zafascynowanych technologiami komputerowymi. Osobliwa, krzykliwa moda również może nastręczać pewnych problemów, jednakże w tekście można napotkać interpretację, że jest to raczej chęć symbolicznego przeniesienia się do świata wolnych w swoich konsumpcyjnych wyborach jednostek, niż po prostu epatowanie drogimi ubraniami [Szlendak 1997].

Tego typu podejście badawcze, polegające na semiotycznym odczytaniu stylu i traktowaniu subkultur jako tekstu, ma swoje korzenie w szkole z Birmingham. W późniejszych latach było ono krytykowane i oskarżane o „nadmierną fantazję", a także o niewspółmierność opisu badaczy z tym, jak interpretowali swój udział w subkulturze sami jej uczestnicy [por. Hebdidge 1979, por. Wróblewski 2012, Muggleton 2004: 24]. To, jak traktowali swój ubiór uczestnicy techno party pozostaje niewiadomą, ponieważ Szlendak nie prowadził z nimi wywiadów. Czytając artykuł z 1997 roku, jesteśmy zatem zmuszeni do zaufania badaczowi i przyjęcia, że prawidłowo odczytał znaczenie stylu uczestników imprez techno.

4 Simon Frith pisze o „naturalności” i „spontaniczności”, używając cudzysłowu, sugerującego, że w rzeczywistej naturalności i spontaniczności tak naprawdę nie ma. Jest to jednak perspektywa osoby z zewnątrz. Warto zauważyć, że jeżeli wspomniane reguły zostaną zinternalizowane, to bywalcy wydarzeń z muzyką "ludową” rzeczywiście będą się czuli swobodnie i nie będą odbierali istniejących reguł jako czegoś sztucznego lub wymuszonego. 


\section{Socjologiczne kulisy technoparty}

Krytyka podejścia semiotycznego dokonana przez Muggletona możne nieco podważyć zaufanie do wyżej zarysowanej charakterystyki technomanii. Dla mnie, jako osoby bezpośrednio związanej ze sceną tanecznej muzyki elektronicznej, opis ten jest nieco podejrzany ze względu na swoją jednowymiarowość i stwarzanie wrażenia, że znaczenie stylu jest dla wszystkich uczestników takie samo ${ }^{5}$. Wydarzenia znane mi „z pierwszej ręki” dzieli od tych, na które uczęszczał Szlendak dobre kilkanaście lat. Trudno mi jednak oprzeć się wrażeniu, że autor posłużył się stereotypami, tworząc obraz przerysowany, a wręcz karykaturalny.

Jak już wspomniałem, Szlendak nie ograniczył się do badań zza biurka. Prowadził też obserwację uczestniczącą na imprezach techno. Niemniej, czytając artykuł, można odnieść wrażenie, że część dotyczącą badań terenowych wykorzystano w niewielkim stopniu. Szlendak jest skłonny raczej do snucia teoretycznych dywagacji dotyczących przekładalności osobistych doświadczeń badacza na język nauki i wyrażania wątpliwości co do prawomocności samej metody, niż do dzielenia się swoimi obserwacjami.

Próba czasu pokazuje, że metoda obserwacji uczestniczącej, mimo rozlicznych wątpliwości, nie przeszła do antropologicznego lamusa. Przeciwnie, jest nadal stosowana, a zmaganie $z$ trudami i znojami pracy terenowej wciąż służy do budowania antropologicznego autorytetu [Nowak 2010]. Niechęć Szlendaka dziwi więc tym bardziej. Dopiero rok później w książce Technomania. Cyberplemięw zwierciadle popkultury, która prawdopodobnie cieszyła się mniejszym kręgiem odbiorców niż prestiżowe „Studia Socjologiczne”, Szlendak zrywa ze swoją początkową rezerwą i decyduje się opisać imprezy techno bardziej „od kuchni” [Szlendak 1998]. Otwarcie relacjonuje swój udział w technoparty.

Okazuje się, że odwiedzał je w latach 1992-1995, wraz ze swoją ówczesną narzeczoną, jako zwykły, chcący się zabawić uczestnik. Dopiero w latach 1996-1997 przeprowadził cztery wizyty już z bardziej badawczym nastawieniem. Z racji efemerycznego charakteru wspólnoty uczestników imprezy techno, trudno jest powiedzieć, że Szlendak zajmował względem

\footnotetext{
Autor niniejszego tekstu uczęszcza na wydarzenia klubowe związane z taneczną muzyką elektroniczną o rave’owej proweniencji mniej więcej od 2009 roku. Od 2013 odwiedza także rave’y oraz „free parties" organizowane pod gołym niebem. W ciągu minionego roku uczestniczył w nich również w charakterze DJ-a. Oprócz tego jest na etapie zakładania wraz ze znajomymi własnego soundsystemu, czyli stosunkowo niezależnej grupy organizatorów, DJ-ów, promotorów i innych, posiadającej własny system nagłośnieniowy.
} 
badanego środowiska pozycję „wewnętrzną”. Określenie czym jest owo „wnętrze” jest bowiem dosyć problematyczne [por. Nowak 2010: 138]. $\mathrm{Z}$ pewnością jest on jednak osobą, która oparła swoje opisy na czymś więcej niż kilku okazjonalnych wizytach badacza-laika w obcym dla niego świecie. Obraz jaki prezentuje Szlendak może więc nieco szokować.

Tym, co w opisie najbardziej uderzające jest dekonstrukcja i „odmitologizowanie" wizerunku technoparty zaprezentowanego w artykule z 1997 roku oraz w pierwszej części książki [Szlendak 1997, 1998]. Autor wspomina o wyraźnie widocznym podziale ról wśród imprezowiczów. Zarysowuje barwną typologię uczestników technoparty, wśród których można znaleźć osoby przychodzące "na podryw”, wpadające w trans, imprezowe "gwiazdy", nuworyszów i doświadczonych, dilerów, osoby z zamożnej klasy średniej i wywodzące się z warstw robotniczych, nastolatki, yuppies, trzeźwych raverów i tych zażywających ecstasy lub korzystających z innych farmakologicznych środków wspomagających. Grupy te różniły się znacząco w kwestiach ubioru, zachowania lub też przygotowań do imprezy, co przeczy obrazowi kolektywnego „techno rytuału”, w którym role, statusy i funkcje wszystkich uczestników są chwilowo zawieszone [Szlendak 1998: 62-79].

Badacz zaobserwował też przypadki ostracyzmu opartego na różnicach klasowych, co jawnie godziło w równościową ideologię techno [Szlendak 1998: 70-72]. Za najbardziej jaskrawy przykład odbrązawiającej narracji można jednak uznać opis roli DJ-a na technoparty, którego szczególna pozycja została jedynie lakonicznie wspomniana w 1997 roku. Według obserwacji Szlendaka miał on wyraźny status gwiazdy, o czym świadczyła już sama aranżacja przestrzeni. Stół mikserski znajdował się zwykle na podwyższeniu [Szlendak 1998: 67]. Reakcje publiczności oklaskującej DJ-a lub ostentacyjnie go „bojkotującej”, wielokrotne powtarzanie pseudonimu performera, głośne zapowiadanie przez mikrofon to kolejne elementy wskazujące na istnienie hierarchii - nierówności między osobą grającą a publicznością [Szlendak 1998: 73-74]. Wszystko to sprawia, że technoparty - poznane od strony socjologicznych kulis [por. Goffman 2009] okazuje się być o wiele bliższe dyskursowi muzyki komercyjnej. Jak zatem tłumaczyć zaobserwowane rozbieżności?

Można tutaj przywołać wykorzystywaną przez Szlendaka koncepcję światów społecznych Anselma Straussa, który przewidywał segmentację zjawisk, takich jak technomania. Proces ten polega na powstawaniu wewnętrznych podziałów, których późniejszym efektem jest wykształcenie kilku osobnych subświatów [por. Strauss 1982]. W przypadku techno takimi subświatami były: odłam hedonistyczny, apolityczny i z założenia 
pozbawiony ideologii oraz odłam zaangażowany społecznie, kultywujący neopogańskie, proekologiczne, new age’owe i kontrkulturowe korzenie ruchu rave - „zippisi”.

Szlendak tłumaczy, że drugiego odłamu w Polsce nie ma [Szlendak 1997: 125, Szlendak 1998: 50-51], przez co polscy badacze chcący się nim zajmować są skazani na analizę opartą na literaturze przedmiotu. Metoda taka stwarza oczywiście ryzyko, że socjolog, chcąc nie chcąc, naraża się na powielanie stereotypowego obrazu technoparty. Brak charakterystycznego dla liminoidów zawieszenia statusów społecznych, jaki ujawnia się $\mathrm{w}$ trakcie osobistych obserwacji badacza, nie musi jednak wynikać $\mathrm{z}$ faktu korzystania ze stereotypowych opisów zawartych w prasie, lecz z tego, że jest to cecha charakterystyczna raczej dla zippisowskiego odłamu fenomenu techno [Szlendak 1998: 132]. Rozbieżności mogą więc mieć źródło w tym, że pierwsza, znana ze „Studiów Socjologicznych”, charakterystyka odnosi się do innego subświata niż ta przedstawiona rok później w Technomanii. Szlendak mógł zatem badać nie jeden, lecz dwa różne fenomeny. Dzisiaj trudno jest ocenić, czy rzeczywiście tak było, czy też pierwotny opis z 1997 roku to po prostu wynik nadmiernego zaufania do artykułów prasowych.

\section{Free tekno}

W ciągu dwóch dekad zaszły zmiany, których Szlendak nie przewidywał. Muzyka elektroniczna niekiedy utrzymana w podobnej do technoparty konwencji wciąż liczy sobie wielu zwolenników. Każdego roku w Polsce odbywa się przynajmniej kilka dużych festiwali, takich jak: Mayday, Sunrise Festival czy Audioriver ${ }^{6}$. Oprócz tego, w całym kraju można napotkać cykliczne imprezy z muzyką elektroniczną, odwiedzane jednorazowo przez kilkaset osób lub więcej. Jeśli wziąć pod uwagę nie tylko największe wydarzenia, ale również dalsze „odpryski” zjawiska gwałtownego rozwoju elektronicznej muzyki tanecznej, materiału do analizy i opisu starczyłoby na całe tomy. Rozwój sieci, forów internetowych, mediów społecznościowych, serwisów, takich jak: nk czy facebook, stworzył nieistniejące dawniej szanse i możliwości w prowadzeniu socjologicznych badań nad muzyką w sposób niebezpośredni. To spory krok od czasów, w których Szlendak, badając

6 Mayday przyciąga kilkanaście tysięcy osób w ciągu jednego dnia, Kołobrzeski Sunrise Fesitval 80 tysięcy w ciągu trzech dni, Audioriver nawet do 30 tysięcy osób w ciągu trzech dni, https://sunrisefestival.pl/info-o-festiwalu, [31.07.2017], http://slaskie.naszemiasto.pl/artykul/relacja-tak-bylo-namayday-2015-w-katowickim-spodku-zdjecia,3564602,artgal,t,id,tm.html, [31.07.2017], http://www. audioriver.pl, [31.07.2017]). 
nieobecnych w Polsce hippisów, skazany był na analizę artykułów prasowych [Szlendak 1997: 125].

Tym bardziej zaskakuje więc, że tematyka spotyka się z tak małym zainteresowaniem ze strony socjologów, etnologów, etnomuzykologów czy też badaczy z pokrewnych dyscyplin naukowych ${ }^{7}$. Prace Tomasza Szlendaka są właściwie jedynymi na polskim gruncie opracowaniami z zakresu socjologii muzyki, poświęconymi w pełni elektronicznej muzyce tanecznej. Trudno podejrzewać, że wynika to z jakiejś szczególnej niechęci badaczy do omawianych środowisk muzycznych. Socjologia muzyki w Polsce w zasadzie od zawsze była nielicznie reprezentowaną subdyscypliną, stojącą na granicy bytu i niebytu [por. Socha 2011]. Luki powstałej przez te wszystkie lata nie można w prosty sposób wypełnić. W spółczesny badacz, mierzący się z barwną mozaiką światów i subświatów muzycznych, musi ograniczyć się do jednego lub maksymalnie kilku środowisk lub subkultur. Nawet wtedy opisanie ich w sposób wyczerpujący wymaga ogromnego nakładu pracy.

Cel, jaki zamierzam osiągnąć jest zatem dużo skromniejszy i polega na weryfikacji roli DJ-a w jednym ze środowisk muzycznych, które do dzisiaj kultywuje zasady i idee obecne w pierwszych latach rave'u. Pojęcie „DJ” stosuję w szerokim rozumieniu. Chodzi tu nie tylko o osoby miksujące gotowe utwory przy użyciu gramofonów, DJ-skich odtwarzaczy płyt CD, kontrolerów czy też komputerów, ale również wykonawców tworzących muzykę na żywo za pomocą tak zwanych maszynek, czyli urządzeń, takich jak samplery czy kontrolery MIDI.

O jakim środowisku mowa? Chodzi o nurt „free tekno” związany bezpośrednio ze wspomnianym już ruchem „free party”, a więc mniej „oswojoną” odmianą rave'u. Za „ojców założycieli” free tekno uznaje się powstały w Wielkiej Brytanii kolektyw Spiral Tribe. Jego członkowie już na początku lat dziewięćdziesiątych XX wieku organizowali wolne od niemal wszelkich regulacji imprezy w pustostanach, na squattach czy nawet w mieście. W 1991 roku przywieźli system nagłośnieniowy, mający 4,5kW efektywnej mocy głośników, nieopodal Stonehenge, a następnie w pobliże wzgórza Brown Wille, organizując tam spontanicznie wielodniowe, darmowe, otwarte dla wszystkich imprezy, nazywane później „teknivalami”, od połączenia słów „tekno” oraz „festival” [Collin 2006: 244, Cybulski 2011].

Nie jest do końca prawdą, że socjologia muzyki elektronicznej jest całkowicie ignorowana. Wiadomo mi przynajmniej o kilku pracach magisterskich poświęconych tejże tematyce. Niemniej jednak, według mojej najlepszej wiedzy, żadna z nich nie doczekała się publikacji. 
Teknivale charakteryzuje podejście dalekie od tego, które opisywał Szlendak. W dyskursie poświęconym free tekno kładzie się nacisk na antyestabilishmentowe i proekologiczne postawy, sprzeciw wobec konsumpcjonistycznego stylu życia, ideologię DIY (Do It Yourself - zrób to sam). Zdarza się też, że free tekno inkorporuje idee nawiązujące do zachodnich tradycji ezoterycznych. Centralnym elementem przestrzeni imprezy jest najczęściej nie stanowisko DJ-a, ale ściana zbudowana $\mathrm{z}$ estradowych kolumn głośnikowych, ułożonych jedne na drugich, na modłę jamajskich soundsystemów, związanych z muzyką dub i reggae. Free tekno ma zresztą z jamajską kulturą soundsystemową sporo wspólnych elementów [por. Partridge 2010, Babylon 1980, Dub Stories 2006, Dub Echoes 2008].

Muzyka, jaką można usłyszeć na teknivalu jest, w porównaniu z klubowymi standardami, bardzo szybka i energiczna. Często spotykane style to: hardtek, tribe, mental, acidcore, acid techno, hard house, hard trance, drum and bass, jungle, hardcore (a zwłaszcza jego odmiana przeznaczona do grania na otwartej przestrzeni - frenchcore), breakcore, speedcore. Tempo oscyluje zwykle w granicach od 170 do 200 uderzeń na minutę, choć zdarzają się czasem utwory mające zaledwie 130 lub aż 300 BPM (Beats Per Minute) $)^{8}$.

Dokładniejsze scharakteryzowanie poszczególnych stylów muzycznych przekroczyłoby ramy tego tekstu. Szczegółowy opis muzykologiczny nie jest zresztą przedmiotem zainteresowania socjologa. Tym bardziej, że, jak zauważył Frith [2011: 116], gatunki muzyczne funkcjonują raczej jako skondensowana argumentacja socjologiczna i ideologiczna, niż jako sztywna rama określająca techniczne aspekty muzyki. Dużo ważniejszą rzeczą są okoliczności, gatunkowo-normatywne sposoby słuchania [Stockfelt 2010] i, generalnie rzecz biorąc, to, w jaki sposób muzyka funkcjonuje w społeczeństwie.

Teknivale to wydarzenia pozbawione formalnej ochrony, większości odgórnych regulacji, kładące nacisk na partycypację. Wyraża się to między innymi w popularnym haśle „You are the party” - „to ty tworzysz imprezę, które można znaleźć chociażby w tzw. tekalogu, czyli liście dziesięciu teknivalowych „przykazań” ${ }^{2}$, które często zamieszcza się na przykład w opisach

8 Uderzające, że Szlendak, opisując techno, określił je jako „niezwykle szybką muzykę", podając tempo 130 uderzeń bębna rytmicznego na minutę [Szlendak 1997: 115].

9 „Przykazania” te można przetłumaczyć w następujący sposób: 1. Szanuj naturę. 2. Szanuj siebie. 3. Szanuj innych. 4. Jeśli nie chcesz zostawiać psa w domu, opiekuj się nim. 5. Parkuj mądrze. 6. Informację o imprezie zatrzymaj tylko dla siebie i swych przyjaciół. 7. Jesteś odpowiedzialny za bezpieczeństwo swoje i innych. Jeśli widzisz coś złego: przemoc, agresję lub coś innego, nie wahaj się. Reaguj. 8. Nie kradnij i nie niszcz ekwipunku soundsystemu. 9. Szerz empatię. 10. Uśmiechaj się, przekazuj dobrą energię, miej pozytywne podejście i pamiętaj - to ty tworzysz imprezę, za: https://a1-images. myspacecdn.com/images01/76/cedb5b802f4a0e0dccc2a5b021d97af1/300x300.jpg, [02.08.2017]). 
wydarzeń w mediach społecznościowych lub na forach internetowych. Informacja o miejscu, w którym odbywa się impreza, jest często utrzymywana w tajemnicy, ze względu na możliwe reperkusje prawne, a także po to, by mieć pewność, że dotrą na nią uczestnicy, którzy będą wiedzieli, na czym ona polega [Collin 2006, Cybulski 2011, Nieżytboy 2013, Sokalla 2016, 23 Minute Warning - Spiral Tribe - World Traveller Adventures 1994, Freetekno 2011, Heretic. We Had a Dream 2010, Il respiro del mostro 2011, Notes on Breakcore 2006].

\section{Cele badania}

Wybór tak wąskiego problemu badawczego, jakim jest rola DJ-a w undergroundowej kulturze free tekno podyktowany został zarówno względami merytorycznymi, jak i praktycznymi.

Po pierwsze, podobny problem był poruszany przez Szlendaka, dzięki czemu mimo upływu lat, możliwe jest zachowanie pewnej ciągłości tematycznej w ramach socjologii muzyki. Pozwala to na rzadko spotykaną kumulację wiedzy w ramach tejże subdyscypliny [por. Socha 2011].

Po drugie, świadome zacieranie różnicy i zmniejszanie dystansu między wykonawcami a odbiorcami jest jednym $\mathrm{z}$ wyznaczników pozwalających scharakteryzować środowisko muzyczne w odniesieniu do Frithowskich kategorii dyskursu artystycznego, ludowego i masowego [por. Frith 2011: 45-47]. Ideologia muzyki „ludowej” zakłada, że kontakty międzyludzkie powinny być naturalne, spontaniczne, bezpośrednie, dystans między wykonawcą a publiką powinien być minimalizowany, wydarzenia muzyczne powinny opierać się na ideach partycypacji, wspólnotowości i egalitarności. Obecny jest w niej sprzeciw wobec kultury scentralizowanej, technokratycznej, bezosobowej, opartej na ścisłych podziałach funkcji, ról, zadań i celów. Zacieranie barier między DJ-em a resztą uczestników może zatem służyć za wskaźnik realizacji ideologicznych postulatów w praktyce.

Po trzecie, temat ten stwarza okazję do przetestowania innej tezy Fritha, piszącego że: „socjologia porównawcza pokazuje, iż różnice pomiędzy muzycznymi światami są dużo mniej wyraziste, niż wynikałoby to $z$ wartości obecnych w ich dyskursach" [Frith 2011: 58]. Autor ten argumentuje, że podobieństwa będą się pojawiały mimowolnie, choćby dlatego, że niezależnie od ideologicznych różnic, w każdym muzycznym świecie pojawiają się podobne wyzwania związane $\mathrm{z}$ organizacją wydarzeń muzycznych, kształtowaniem się ról twórców czy wykonawców, a także koniecznością radzenia sobie ze zmianami, jakie przyniósł ze sobą rozwój społeczeństwa 
przemysłowego u schyłku XVIII wieku [Frith 2011: 58]. W podobnym duchu wypowiadali się również niektórzy przedstawiciele szkoły z Birmingham nazywanej czasem szkołą CCCS (Centre for Contemporary Cultural Studies), także Pierre Bourdieu, podkreślając, że różnice ideologiczne bywają wyolbrzymiane [Bourdieu 2007, por. Wróblewski 2012, por. Muggleton 2004: 22-24].

Do wspomnianych zmian $\mathrm{w}$ funkcjonowaniu muzyki można zaliczyć między innymi proces utowarowienia muzyki, z którym wiązało się kształtowanie się kanałów dystrybucji, zawodów związanych z muzyką oraz powstawanie miejsc przeznaczonych do jej tworzenia oraz wykonywania. Dany świat muzyczny musi zawsze operować opierając się pewnej "materialnej bazie”, czyli instytucjonalnych warunkach określających ramy jego funkcjonowania, takie jak: miejsce tworzenia muzyki i odbywania się wydarzeń, czas w jakim się one odbywają, sposób w jaki funkcjonują muzycy i obsługa wydarzeń (np. to czy są profesjonalistami czy też nie). Materialna baza może ograniczać realizację niektórych ideologicznych postulatów funkcjonujących w danym dyskursie muzycznym. Przykładowo, trudno jest wdrażać idee inkluzywności i egalitarności, organizując wydarzenia muzyczne $\mathrm{w}$ wynajętym klubie, $\mathrm{z}$ profesjonalną obsługą, ochroną i sprzętem estradowym, za które trzeba zapłacić odpowiednią sumę. Wysokie koszty, jakie ponosi organizator w związku z wynajmem mogą zmuszać go do działania w sposób pozwalający na zwrócenie się kosztów imprezy. Najprostszą metodą na zwiększenie zysków jest podniesienie cen biletów, co stwarza zaporę dla tych, którzy nie chcą lub nie mogą wydać większej sumy na wstęp. Klub muzyczny może narzucać sposób, w jaki impreza jest reklamowana, maksymalny czas jej trwania, aranżację przestrzeni, zasady, na jakich dystrybuowane są napoje oraz jedzenie (np. niektóre kluby nie życzą sobie, żeby organizatorzy rozdawali darmową wodę, ponieważ zmniejsza to dochody „z baru”), ceny, a także wiele innych czynników mających wpływ na to, czy wartości obecne w danym świecie muzycznym znajdą swoje odzwierciedlenie. Limitowany czas trwania wydarzenia ogranicza liczbę występujących wykonawców, a to $\mathrm{z}$ kolei prowadzi do profesjonalizacji i nadania szczególnego statusu tym, którzy pełnią taką rolę. Kontrola nad materialną bazą jest więc zmienną pośredniczącą $\mathrm{w}$ realizowaniu ideologicznych postulatów funkcjonujących w określonym dyskursie muzycznym.

$\mathrm{W}$ świecie free tekno, zanurzonym w dyskursie egalitarnym, gwiazdorstwo z pewnością nie jest czymś mile widzianym. Badanie imprez 
w warunkach nieklubowych stwarza więc okazję do zweryfikowania, na przykładzie roli DJ-a, czy i na ile realia odbiegają od ideologicznych założeń w sytuacji, w której to uczestnicy sceny mają kontrolę nad bazą materialną.

Czwartym czynnikiem, który zadecydował o wyborze tematu jest znajomość środowiska free tekno w Polsce, która umożliwiła uzupełnienie analizy ilościowej skromnym badaniem jakościowym, opartym na obserwacji uczestniczącej. Badanie ilościowe polegało przede wszystkim na analizie istniejącego materiału filmowego, udostępnianego publicznie za pośrednictwem serwisu youtube.com. Metoda ta, choć z pewnością daleka jest od doskonałości, pozwala na badanie zjawiska w sposób nieco bardziej bezpośredni niż za czasów Szlendaka. Dzięki filmom, głównym przedmiotem badania stają się same praktyki muzyczne, co jest zgodne $\mathrm{z}$ najnowszymi postulatami funkcjonującymi w socjologii muzyki [por. Jabłońska 2014: 129-131, 143-144]. Oczywiście, żadne badanie oparte na zdjęciach, filmach, wywiadach czy też opisach nie będzie spełniać pozytywistycznych postulatów badania rzeczywistości społecznej jako takiej, w którym badacz, niczym przyrodnik, wolny jest od wpływów społecznych i interpretacji. Mam jednak wrażenie, że oparcie analizy na surowym materiale filmowym (tzn. niepoddanym późniejszemu montażowi), zamiast na opisie sporządzonym na podstawie takiego materiału, pozwala na dotarcie w sposób bardziej bezpośredni do subiektywnych doświadczeń autorów filmów dzięki skróceniu łańcucha pośredników o jedno ogniwo.

Celem badania jest próba falsyfikacji hipotezy o zatarciu dystansu między uczestnikami a wykonawcami $\mathrm{w}$ ramach free parties. Zgodnie z Popperowską filozofią nauki, hipotezy należy próbować obalać, zamiast je potwierdzać. Dopiero nieudana próba falsyfikacji może w pewnym stopniu służyć jako pozytywna weryfikacja [Popper 1977]. Jestem świadomy tego, że zwykło się uważać, że badania ilościowe służą raczej eksploracji tematyki niż weryfikacji czy też falsyfikacji konkretnych hipotez [Banks 2009: 32]. Nie widzę jednak powodu, dlaczego wizualne badanie ilościowe nie mogłoby służyć takiemu celowi, jeżeli tylko kryteria analityczne zostały określone na tyle szczegółowo, żeby nie zostawiać zbyt szerokiego pola do interpretacji badaczowi, zwłaszcza w przypadku, kiedy jest on osobiście zaangażowany w świat, który bada. Jedyny zarzut, jaki można tutaj wysunąć polega na tym, że próba dobrana na podstawie o kryterium dostępności nie może być reprezentatywna, a to może podważać zaufanie do weryfikacyjnej mocy badania. Oczywiście idealną sytuacją byłoby dysponowanie 
operatem zawierającym filmy ze wszystkich możliwych imprez free tekno, a następnie wylosowanie $\mathrm{z}$ niego próby losowej. Jak łatwo się domyślić, spełnienie takiego wymogu nie jest możliwe. W tej sytuacji uważam, że dopuszczalne jest zaakceptowanie próby niereprezentatywnej, ale nieobciążonej żadnym widocznym błędem systematycznym, który mógłby wpłynąć na zafałszowanie wyników.

\section{Metodologia badania ilościowego}

Badanie zostało przeprowadzone przeze mnie w czerwcu 2014 roku w ramach seminarium tematycznego poświęconego formom komunikacji w kulturze współczesnej, prowadzonego przez dr hab. Izabelę Trzcińską w Katedrze Porównawczych Studiów Cywilizacji Uniwersytetu Jagiellońskiego w roku akademickim 2013/2014.

Analizie zostało poddanych sto filmów zamieszczonych na portalu youtube.com. Wyszukiwano je po hasłach: „free party” oraz „teknival”. Oparcie się tylko na jednym tagu sprawiłoby dużo problemów, ponieważ po jakimś czasie w wynikach pojawiałyby się również materiały zupełnie niezwiązane z przedmiotem badania. Konieczne było więc zastosowanie przynajmniej dwóch haseł. Kryteria, na podstawie których stwierdzano, że materiał nie przedstawia opisywanego zjawiska były następujące: (1) muzyka - odrzucano materiały, w których można było usłyszeć zupełnie inne gatunki muzyczne niż te, o których była do tej pory mowa, czyli na przykład trance, dubstep, house, elektro; (2) tagi dodatkowe - nie uwzględniano filmów opisanych jako „music festival”, ponieważ rzeczą charakterystyczną dla sceny free tekno jest używanie nazwy „teknival” zamiast „festival”; (3) przestrzeń - z badania wyłączono filmy nakręcone w klubach muzycznych, gdyż nawet jeśli grano w nich muzykę charakterystyczną dla „free party”, to prawdopodobnie uczestnicy i organizatorzy nie mieli wpływu na aranżację przestrzeni czy ustawienie głośników.

Filmy analizowano w takiej kolejności, w jakiej pojawiały się w wynikach wyszukiwania, pomijając tylko te, które nie spełniały wspomnianych wyżej kryteriów. Wzięto pod uwagę po pięćdziesiąt filmów wyszukanych na podstawie każdego z tagów. W trakcie badania, rolę DJ-a analizowano opierając się na trzech elementach. Były to: (1) stopień zainteresowania operatora osobą DJ-a, (2) stopień zainteresowania DJ-em wśród osób bawiących się, (3) ekspozycja DJ-a, czyli na przykład zaaranżowanie przestrzeni. Wzięcie pod uwagę wszystkich trzech elementów pozwoliło na uwzględnienie zarówno tak zwanej narracji wewnętrznej (co znalazło 
się na filmie?), jak i zewnętrznej (kto nakręcił film? z jakiego powodu?), [por. Banks 2009: 38-39].

Zaprojektowanie badania wizualnego w taki sposób włącza perspektywę nie tylko operatora kamery i uczestników, ale także organizatorów odpowiedzialnych za rozmieszczenie głośników czy stołu mikserskiego. Podejście to uwzględnia zatem wszystkich teknivalowych „interesariuszy”. W każdym ze stu filmów wszystkie trzy elementy oceniono za pomocą dyferencjału semantycznego. Dodatkowo przyjęto wskaźniki mające pomóc w obiektywizacji oceny:

1. Uwaga operatora: 1 - DJ zupełnie nieistotny, 7 - DJ głównym obiektem zainteresowania. Wskaźniki pomocnicze: wyostrzenie obrazu na postać DJ-a, DJ w centrum lub w jednym z wynikających z zasady trójpodziału mocnych punktów kadru, stosunkowo długi czas poświęcony postaci DJ-a w porównaniu do publiki, otoczenia, sprzętu itd. [por. Banks 2009: 37-41].

2. Uwaga uczestników: 1 - uczestnicy nie zwracają uwagi na DJ-a, 7 - uczestnicy traktują DJ-a jako centralną postać. Wskaźniki pomocnicze: uczestnicy starają się nawiązywać interakcję z DJ-em, uczestnicy gromadzą się $\mathrm{w}$ miejscu umożliwiającym obserwację DJ-a, uczestnicy są zwróceni twarzą w kierunku DJ-a, uczestnicy wykrzykują pseudonim DJ-a [por. Banks 2009: 37-41, por. Szlendak 1998: 73-74].

3. Ekspozycja DJ-a: 1 - DJ ukryty, niewidoczny, 7 - DJ wyraźnie wyeksponowany. Wskaźniki pomocnicze: dekoracja dookoła DJ-a, DJ jest widoczny/niezasłonięty, scena/stół mikserski są umieszczone na podwyższeniu, stanowisko DJ-a w centrum, między głośnikami (a nie np. $z$ boku), widoczny pseudonim DJ-a, DJ jest zapowiadany lub zwraca na siebie uwagę, na przykład przez mikrofon [por. Banks 2009: 37-41, por. Szlendak 1998: 67, 73-43].

Analizę materiału filmowego zwykle komplikuje fakt, że jest on poddany montażowi [Banks 2009: 88-90). Zdecydowana większość badanych filmów była jednak zamieszczana na youtube.com bez żadnej wcześniejszej obróbki, w stanie surowym. Co więcej, amatorski charakter nagrań, reagowanie na muzykę skutkujące drganiem obrazu czy brak reakcji na operatora kamery ze strony innych imprezowiczów pozwalają przypuszczać, że ich autorami byli zwykli uczestnicy. Można zatem ostrożnie założyć, że nagrania przedstawiały doświadczenie uczestnika imprezy, co należy uznać za korzystny zbieg okoliczności, jako że przedmiotem badania jest analiza relacji uczestników z osobą pełniącą w danym momencie rolę DJ-a. 


\section{Metodologia badania jakościowego}

Badanie ilościowe uzupełniają dane pozyskane $\mathrm{w}$ czasie obserwacji uczestniczącej przeprowadzonej na 300 różnych wydarzeniach, odbywających się w latach 2013-2017 w Polsce, w województwach: pomorskim, kujawsko-pomorskim, zachodniopomorskim, dolnośląskim oraz małopolskim ${ }^{10}$. Zdecydowałem się nie podawać dokładnych miejsc, dat ani nazw opisywanych wydarzeń, dlatego że ich organizatorzy lub uczestnicy mogliby sobie tego nie życzyć, chcąc utrzymać undergroundową specyfikę sceny. Drugim powodem jest to, że nie dysponuję informacją czy we wszystkich przypadkach miejsce imprezy zostało formalnie zalegalizowane ${ }^{11}$. Nieujawnianie pewnych informacji jest więc związane $\mathrm{z}$ obowiązkiem ochrony osób badanych.

Dziesięć z opisywanych wydarzeń odbyło się pod gołym niebem. Pozostałe pod dachem, w miejscach niezwiązanych w żaden sposób z działalnością muzyczną, ani kulturalną, pozbawionych podstawowego zaplecza w postaci wody, prądu, ogrzewania, mebli, stałego nagłośnienia czy nawet drzwi wejściowych. Z badania wyłączono imprezy klubowe oraz te odbywające się w niezależnych placówkach kulturalnych. Dzięki temu analizowane wydarzenia nie różnią się specjalnie od tych będących przedmiotem badania ilościowego.

Pierwsze cztery z nich odwiedziłem w latach 2013-2015. Nie planowałem jeszcze wtedy zajęcia się socjologią muzyki, którą interesuję się od 2015 roku. Nawet wtedy jednak, moje uczestnictwo nigdy nie było w stu procentach motywowane badawczo. Towarzyszyła mi jeszcze chęć poznania ludzi, zabawy, a także zdobycia wiedzy na temat sprzętu estradowego oraz organizacji wydarzeń muzycznych. W trzech przypadkach miałem również okazję znaleźć się po drugiej stronie stołu mikserskiego i pełnić rolę DJ-a. Po każdym z wydarzeń została sporządzona notatka terenowa oparta na

10 Zdaję sobie sprawę, że przedmiotem analizy w czasie obserwacji uczestniczącej powinno być samo doświadczenie uczestnictwa badacza. Prezentowane przeze mnie dane można by z powodzeniem uzyskać na podstawie obserwacji nieuczestniczącej. Obserwacja uczestnicząca była prowadzona w ramach szerszego projektu badawczego, niezwiązanego bezpośrednio z niniejszym tekstem. Dane były zatem zbyt obszerne. Zdecydowałem się więc zawęzić je do informacji o aranżacji przestrzeni i relacji między DJ-em a resztą uczestników.

11 Niekiedy zdarza się, że organizatorzy imprez rave lub free parties porozumiewają się z osobami, którym hałas mógłby ewentualnie przeszkadzać i ustalają wspólnie zasady dotyczące poziomu głośności, czasu trwania imprezy, wywozu śmieci. Dzięki temu wydarzenia mogą się odbywać mimo braku oficjalnych zezwoleń ze strony decydentów lub bez wiedzy służb porządkowych. Czasami są one organizowane w miejscach na tyle odludnych, że odbywają się bez jakichkolwiek ustaleń. 
własnych doświadczeniach, fotografiach i filmikach, a także na zdjęciach, filmach i postach zamieszczonych później przez innych uczestników na stronach wydarzeń na facebooku, blogach, forach internetowych. Pomoce te służyły jako „odświeżacz pamięci”, co było bardzo przydatne, zważywszy na to, że trudno jest niekiedy spamiętać wszystkie szczegóły z wydarzenia trwającego nawet kilkadziesiąt godzin, zwłaszcza kiedy notatki były sporządzane po upływie dłuższego czasu.

Uzupełnienie badania ilościowego, zapośredniczonego przez serwis youtube.com, bezpośrednią analizą jakościową jest zgodne $\mathrm{z}$ zaproponowanym przez Krzysztofa Koneckiego postulatem triangulacji technik badawczych [Konecki 2000: 16-23]. Zbieranie jednocześnie „socjologicznych” i „antropologicznych” danych pozwala przeciwdziałać uzyskaniu mało wnikliwej, czysto statystycznej analizy przy równoczesnym ograniczeniu zbyt daleko idących odautorskich „(nad)interpretacji” [Fatyga 2005: 177]. Stosowanie triangulacji technik ma tę niewątpliwą zaletę, że pomaga uniknąć niebezpieczeństw, jakie wiążą się ze stosowaniem danych technik badawczych osobno. Słabsze strony jednej techniki mogą być skutecznie uzupełniane za pomocą innej. Jednym $\mathrm{z}$ takich niebezpieczeństw może być „błąd reifikacji”, który popełniają niekiedy badacze jakościowi. Polega on na tym, że badacz nie odróżnia swojego osobistego stosunku do przedmiotu badania od niego samego i nie zdaje sobie sprawy $z$ tego, że niektóre treści są wywoływane przez samego badacza, z natury doszukującego się znaczeń, które mogłyby stać się przedmiotem jego analizy [Bourdieu, Wacqant 1992: 68-70]. Badanie ilościowe na treściach zastanych pozwala przynajmniej częściowo upewnić się, czy omawiana tendencja do „antyekspozycji” postaci DJ-a w środowisku free tekno rzeczywiście ma miejsce, a nie jest zaledwie nadinterpretacją. Widać zatem, że stosowanie równocześnie kilku technik badawczych pozwala antropologii społecznej, a także pokrewnym dziedzinom nauk społecznych utrzymać status „nauki sceptycznej” [por. Firth 2003: 21].

\section{Wyniki uzyskane na podstawie analizy materiału wizualnego}

Prezentację wyników rozpocznę od przedstawienia trzech wykresów słupkowych obrazujących rozkład wartości w dyferencjale semantycznym dla: uwagi operatora, uwagi uczestników oraz ekspozycji DJ-a. Wartość 1 opisuje minimalne, a wartość 7 maksymalne natężenie cechy, wartości od 2 do 6 przedstawiają pośrednie stopnie natężenia. Dla braku danych przewidziano wartość 8 . Oprócz wykresów słupkowych, przedstawiono również 
tabele wyników dla każdej zmiennej, a także tabelę zawierającą informacje dotyczące wartości kwartyli: dolnego, mediany i górnego dla wszystkich trzech badanych rozkładów.

\section{Wykres 1. Uwaga operatora}

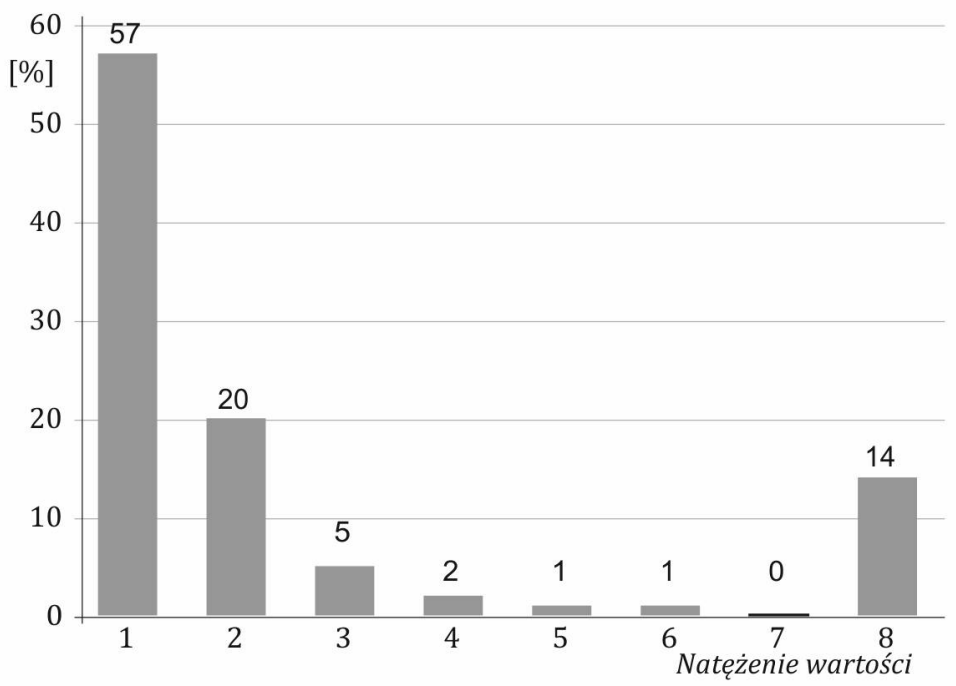

Tabela 1. Uwaga operatora

\begin{tabular}{|c|c|c|c|}
\hline Wartość & Liczba wskazań & Procent ważnych & $\begin{array}{c}\text { Skumulowany } \\
\text { procent ważnych }\end{array}$ \\
\hline 1 & 53 & 54,08 & 54,08 \\
\hline 2 & 20 & 20,41 & 74,49 \\
\hline 3 & 10 & 10,20 & 84,69 \\
\hline 4 & 5 & 5,10 & 89,80 \\
\hline 5 & 5 & 5,10 & 94,90 \\
\hline 6 & 5 & 5,10 & 100,00 \\
\hline 7 & 0 & 0,00 & 100,00 \\
\hline Brak danych & 2 & \multicolumn{2}{|c|}{} \\
\cline { 1 - 2 } Razem ważnych & 98 & &
\end{tabular}




\section{Wykres 2. Uwaga uczestników}

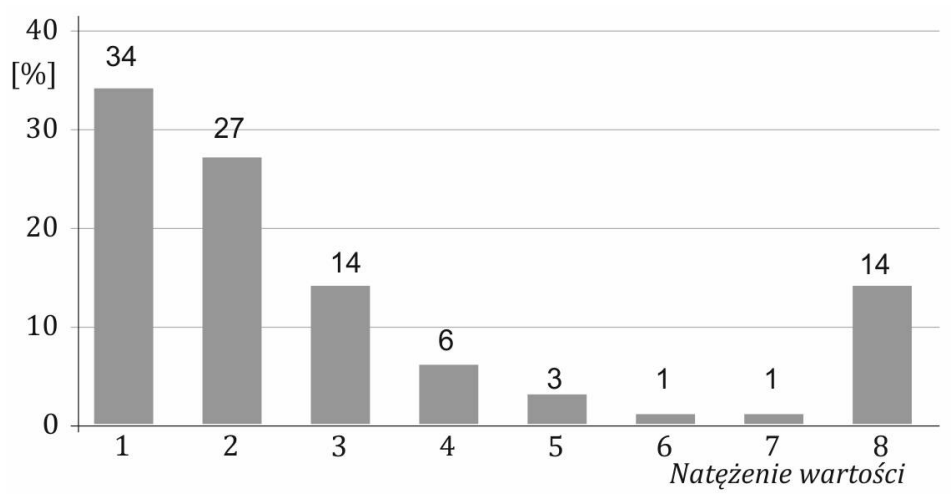

Tabela 2. Uwaga uczestników

\begin{tabular}{|c|c|c|c|}
\hline Wartość & Liczba wskazań & Procent ważnych & $\begin{array}{c}\text { Skumulowany procent } \\
\text { ważnych }\end{array}$ \\
\hline 1 & 57 & 66,28 & 66,28 \\
\hline 2 & 20 & 23,26 & 89,53 \\
\hline 3 & 5 & 5,81 & 95,35 \\
\hline 4 & 2 & 2,33 & 97,67 \\
\hline 5 & 1 & 1,16 & 98,84 \\
\hline 6 & 1 & 1,16 & 100,00 \\
\hline 7 & 0 & 0,00 & 100,00 \\
\hline Brak danych & 14 & & \\
\hline Razem ważnych & 86 & & \\
\hline
\end{tabular}




\section{Wykres 3. Ekspozycja DJ-a}

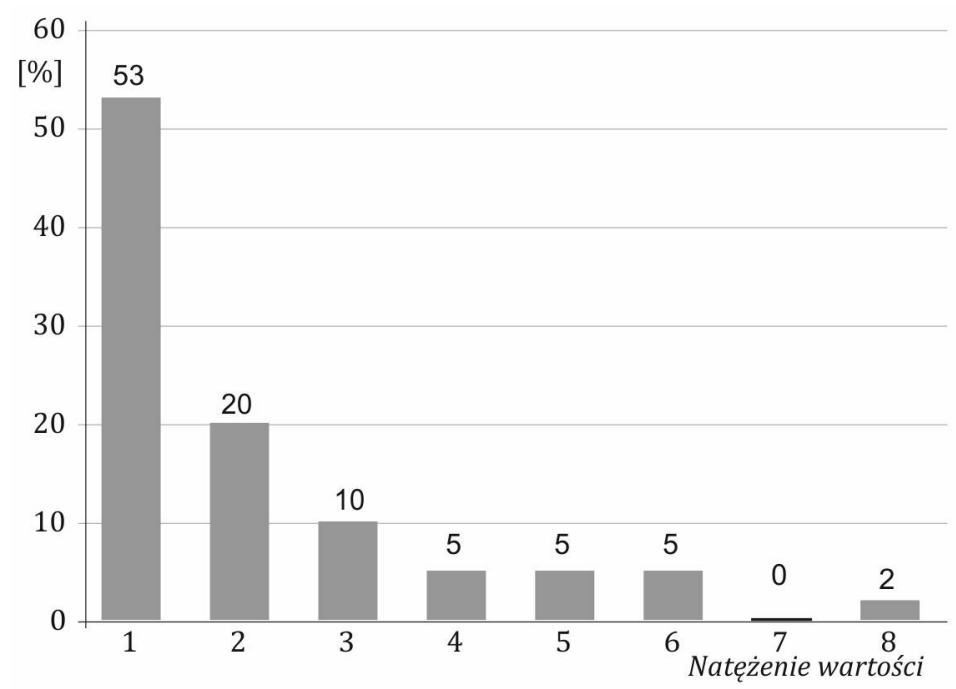

Tabela 3. Ekspozycja DJ-a

\begin{tabular}{|c|c|c|c|}
\hline Wartość & Liczba wskazań & Procent ważnych & $\begin{array}{c}\text { Skumulowany procent } \\
\text { ważnych }\end{array}$ \\
\hline 1 & 34 & 39,53 & 39,53 \\
\hline 2 & 27 & 31,40 & 70,93 \\
\hline 3 & 14 & 16,28 & 87,21 \\
\hline 4 & 6 & 6,98 & 94,19 \\
\hline 5 & 3 & 3,49 & 97,67 \\
\hline 6 & 1 & 1,16 & 98,84 \\
\hline 7 & 1 & 1,16 & 100,00 \\
\hline Brak danych & 14 & & \\
\cline { 1 - 2 } Razem ważnych & 86 & & \\
\cline { 1 - 2 } & \multicolumn{2}{|r|}{} &
\end{tabular}

Tabela 4. Wartości kwartyli

\begin{tabular}{|l|c|c|c|}
\hline \multicolumn{1}{|c|}{ Kwartyl } & Uwaga operatora & Uwaga uczestników & Ekspozycja DJ-a \\
\hline Dolny & 1 & 1 & 1 \\
\hline Mediana & 1 & 1 & 2 \\
\hline Górny & 3 & 2 & 3 \\
\hline
\end{tabular}


Sposób doboru materiału do analizy nie jest pozbawiony wad. Można zgłaszać pewne zastrzeżenia co do spodziewanej rzetelności badania. Pierwsze dotyczy możliwości wystąpienia pewnego błędu systematycznego wpisanego w logikę doboru próby. Materiał wizualny wyszukiwany był po tagach ogólnych. Można się spodziewać, że filmy, na których DJ odgrywa pierwszorzędną rolę częściej noszą tytuł będący pseudonimem artystycznym nagrywanego artysty, a nie na przykład „free party 2012”. Istnieje więc podejrzenie, że wykluczano przypadki, w których DJ miał specjalny status. Drugie możliwe zastrzeżenie dotyczy tego, że czasami badacz zmuszony był zakodować 8 (brak danych) w zmiennej dotyczącej ekspozycji, jeżeli operator w ogóle nie pokazywał DJ-a. Nie wiadomo bowiem było, czy jest on dobrze ukryty, czy po prostu osoba nagrywająca materiał nie skupiła się na jego postaci. Zakładając, że nastawienie operatora było podobne do nastawienia reszty uczestników, można się spodziewać, że imprezy na których DJ był wyjątkowo dobrze schowany były systematycznie wykluczane z badania. Na szczęście zaobserwowane możliwe błędy systematyczne znoszą się nawzajem, ponieważ pierwszy z nich mógłby ewentualnie powodować wykluczenie najbardziej eksponowanych DJ-ów, drugi zaś osoby grające z ukrycia. Ponadto, nie sposób nie zauważyć, że wyniki w tabelach pokazują wyraźnie, że DJ-e są raczej ignorowani niż hołubieni przez operatorów kamery oraz uczestników i w dodatku mają tendencję do zajmowania mało wyeksponowanych czy też wręcz ukrytych pozycji. Trudno oczekiwać, że tak wyraźny trend wynika jedynie $z$ tendencyjnego doboru obserwacji.

\section{Wyniki uzyskane w trakcie obserwacji uczestniczącej}

Tak jak wspomniano wcześniej, obserwacja była prowadzona w trakcie 13 różnych wydarzeń. Ich lista znajduje się w tabeli 5. Nazwy wydarzeń zostały zastąpione skrótem OU_LP, gdzie OU oznacza obserwację uczestniczącą, a LP to liczba porządkowa. Liczba przeanalizowanych wydarzeń nie pokrywa się z liczbą zaobserwowanych przypadków. Niektóre z omawianych imprez miały charakter łączony. Niekiedy w bezpośrednim sąsiedztwie, w ramach jednej imprezy, ustawiano więcej niż jedną scenę. Nie na wszystkich z nich grano muzykę tekno lub pokrewne style muzyczne związane ze sceną free party. Czasami bywało tak, że jedna ze scen poświęcona była tekno, inna muzyce psytrance, a jeszcze inna chilloutowi. Zdarzało się, że na jednej scenie można było usłyszeć zarówno deep techno, jak i tekno, ponieważ czasem dzielono się w różnych proporcjach. 
Wyróżniłem zatem sceny w większości przeznaczone do grania styli kojarzonych powszechnie ze środowiskiem free tekno (np. tribe, mental, frenchcore, acidcore, breakcore) - oznaczone symbolem A, takie, na których style te pojawiały się tylko przez mniej więcej połowę czasu - oznaczone symbolem B, oraz takie na których nie pojawiały się one wcale lub pojawiały się tylko przez stosunkowo krótki moment - opisane za pomocą litery C.

Wydarzenia dające się opisać jako „free party” czy też „teknival” niekiedy trwają nawet kilka dni bez przerwy. Prowadzenie obserwacji od początku do końca jest w takich przypadkach niemożliwe. W tabeli 5 pojawiły się zatem kolumny informujące o tym, jak długo trwało wydarzenie i jak długo prowadzono obserwację, co pozwala na określenie stopnia zaufania do prezentowanych wniosków.

Ostatnia kolumna tabeli 5 dotyczy formy uczestnictwa badacza w wydarzeniu. W 10 z nich brałem udział jako „regularny” uczestnik. W pozostałych trzech pełniłem również funkcję DJ-a. Łącznie udało się przeprowadzić obserwację na 26 scenach. Obserwacje zostały oznaczone w następujący sposób: numer wydarzenia_numer i rodzaj sceny. Przykładowo [OU_03_2C] oznacza drugą ze scen, na której nie grano muzyki tekno, ustawionej na wydarzeniu oznaczonym jako OU_03.

Tabela 5. Obserwacja uczestnicząca

\begin{tabular}{|c|c|c|c|c|c|c|}
\hline Wydarzenie & \begin{tabular}{|c|} 
Sceny tekno \\
(A)
\end{tabular} & $\begin{array}{c}\text { Sceny } \\
\text { półtekno (B) }\end{array}$ & $\begin{array}{c}\text { Sceny } \\
\text { nietekno }(\mathrm{C})\end{array}$ & $\begin{array}{c}\text { Czas trwania } \\
\text { wydarzenia }\end{array}$ & $\begin{array}{c}\text { Czas } \\
\text { obserwacji }\end{array}$ & $\mathrm{W}$ roli $\mathrm{DJ}-\mathrm{a}$ \\
\hline OU_01 & 1 & 0 & 1 & $2 \mathrm{dni}$ & 1 dzień & NIE \\
\hline OU_02 & 1 & 0 & 1 & $12 \mathrm{~h}$ & $7 \mathrm{~h}$ & NIE \\
\hline OU_03 & 1 & 0 & 2 & $2 \mathrm{dni}$ & 1 dzień & NIE \\
\hline OU_04 & 1 & 1 & 1 & $2 \mathrm{dni}$ & $2 \mathrm{dni}$ & NIE \\
\hline OU_05 & 0 & 2 & 0 & $10 \mathrm{~h}$ & $5 \mathrm{~h}$ & NIE \\
\hline OU_06 & 1 & 0 & 0 & $12 \mathrm{~h}$ & $10 \mathrm{~h}$ & NIE \\
\hline OU_07 & 3 & 0 & 0 & 2 dni & 2 dni & NIE \\
\hline OU_08 & 1 & 0 & 0 & 2 dni & 1 dzień & NIE \\
\hline OU_09 & 0 & 2 & 0 & $10 \mathrm{~h}$ & $7 \mathrm{~h}$ & NIE \\
\hline OU_10 & 0 & 1 & 0 & $22 \mathrm{~h}$ & $11 \mathrm{~h}$ & TAK \\
\hline OU_11 & 1 & 0 & 0 & $12 \mathrm{~h}$ & $10 \mathrm{~h}$ & TAK \\
\hline OU_12 & 1 & 0 & 0 & $2 \mathrm{dni}$ & $2 \mathrm{dni}$ & TAK \\
\hline OU_13 & 4 & 0 & 0 & $2 \mathrm{dni}$ & $2 \mathrm{dni}$ & NIE \\
\hline Razem & 15 & 6 & 5 & & & \\
\hline
\end{tabular}


W trakcie prowadzenia obserwacji dało się wyróżnić kilka sposobów aranżacji przestrzeni i ustawienia stanowiska osoby grającej:

- DJ zupełnie niewidoczny, schowany za ścianą głośników lub w innym pomieszczeniu: [OU_03_1A], [OU_04_1A], [OU_05_1B], [OU_09_1B], [OU_13_4A];

- Stanowisko DJ-a do pewnego stopnia widoczne, ale ustawione z boku, w taki sposób, że obrócenie się twarzą w kierunku DJ-a wiązałoby się z odwróceniem się bokiem do systemu nagłośnieniowego, co utrudniałoby odbiór muzyki: [OU_01_1A], [OU_07_1A], [OU_07_2A], [OU_07_3A], [OU_08_1A], [OU_12_1A], [OU_13_ _1A], [OU_13_2A], [OU_13_3A];

- DJ w pozycji centralnej, między głośnikami, ale słabo widoczny $\mathrm{z}$ racji zakrycia stanowiska banerem, pół-przezroczystym ekranem Z wizualizacjami itp.: [OU_02_1A], [OU_06_1A];

- DJ w pozycji centralnej, stanowisko między głośnikami, widoczne, ale w żaden sposób nieeksponowane: [OU_01_1C], [OU_02_1C], [OU_03_1C], [OU_04_1C], [OU_05_2B], [OU_09_2B], [OU_10_ _ 1B], [OU_11_1A];

- DJ widoczny, ale ze stanowiskiem po przeciwnej stronie niż głośniki, dekoracje itd.: [OU_03_2C], [OU_04_1B].

Widać zatem, że rzeczywiście również w trakcie wydarzeń obserwowanych bezpośrednio, stanowisko DJ-a nigdy nie było szczególnie eksponowane. Ani razu nie spotkałem się ze specjalnie zbudowanymi podwyższeniami lub innymi elementami dekoracji mogącymi się przyczynić do udramatyzowania postaci DJ-a. W jednym tylko przypadku - [OU_10_1B] - DJ miał na twarzy maskę, która mogła zwracać uwagę publiki. Nieomal wszystkie przypadki celowego ukrycia DJ-a, lub ustawienia go w pozycji utrudniającej obserwację jego stanowiska dotyczyły scen typu A. Wyjątkiem były tylko dwa przypadki scen typu B, na których przez około $60-70 \%$ czasu grano muzykę pokrewną środowiskom free party, czyli londyńskie acid techno oraz acidcore. Obydwie te sceny można by, przy nieco bardziej liberalnych kryteriach, zaliczyć do kategorii A.

Przypadków pośrednich, w których DJ-a ani nie ukrywano, ani nie eksponowano było osiem. Chodzi tu o te sytuacje, w których stół mikserski umieszczono w pozycji centralnej, bez specjalnych prób ukrycia DJ-a. Połowę z nich stanowią sceny typu $\mathrm{C}$ z muzyką psytrance. Przejdę więc do omówienia pozostałych czterech przypadków typów A i B.

Sceny [OU_05_2B], [OU_09_2B] oraz [OU_11_1A] zbudowano na potrzeby niewielkich wydarzeń, na których niekiedy brakowało miejsca 
i sprzętu. Pierwsze dwa z nich zorganizowano w betonowym pomieszczeniu o powierzchni co najwyżej kilkunastu metrów kwadratowych, w którym trudno byłoby w jakikolwiek sposób ukryć DJ-a. Trzecia $\mathrm{z}$ wymienionych scen została zbudowana przez nowo zawiązującą się grupę, niedysponującą jeszcze sprzętem, z którego można by zbudować całą ścianę głośników, nieposiadającą też swojego banera czy projektora, który można by użyć do zamontowania ekranu z wizualizacjami, oddzielającego DJ-a od publiki. Skromne oświetlenie stołu powodowało, że osoba grająca i tak nie była szczególnie widoczna.

Ostatni przypadek - [OU_10_1B] - dotyczy już nieco większego wydarzenia, na którym organizatorzy dysponowali sprzętem nagłośnieniowym wysokiej klasy oraz dwoma projektorami. Brak specjalnego ukrywania stołu mikserskiego można tłumaczyć na dwa sposoby. Po pierwsze, impreza miała miejsce w wielkiej, półotwartej betonowej hali, której szerokość mogła wynosić nawet 20 metrów. W szczytowym momencie wydarzenia, na parkiecie bawiło się jednocześnie szacunkowo 100-200 ludzi. W takiej sytuacji trudno byłoby rozstawić głośniki w formie zbitej ściany. Pozbawiłoby to sporą część uczestników możliwości komfortowego słuchania muzyki. Po drugie, impreza była nastawiona przede wszystkim na muzykę hardcore, drum and bass oraz crossbreed, będący hybrydą pomiędzy pierwszymi dwoma wymienionymi gatunkami. Za co najmniej połowę puszczanej tam muzyki tekno był odpowiedzialny sam badacz, który zgłosił się na ochotnika do grania w ramach tak zwanych open decków, czyli wolnych, otwartych zapisów. Gdyby nie to, scenę być może należałoby już zaklasyfikować do kategorii C. Można zatem spekulować, że brak ukrycia stołu mikserskiego wiązał się $\mathrm{z}$ charakterem imprezy - nastawionym na free tekno raczej w niewielkim stopniu.

Ostatnie już, do tej pory niewymienione przypadki - [OU_03_2C] i [OU_04_1B] - dotyczą małych (zdecydowanie mniejszych niż główne sceny), postawionych „przy okazji” scen z muzyką chillout oraz z tworzoną na żywo muzyką eksperymentalną, przyciągającą przede wszystkim osoby zajmujące się produkcją muzyki.

W części poświęconej badaniu ilościowemu zwróciłem uwagę na możliwość wywieszania pseudonimów osób grających, co mogłoby się wiązać $\mathrm{z}$ nadawaniem im specjalnego statusu. W trakcie obserwacji dwa razy miałem okazję zaobserwować wywieszoną listę z pseudonimami DJ-ów oraz godzinami, w których mieli oni grać: [OU_01_A1] i [OU_12_A1]. Za każdym razem były to tekturowe kartoniki z podpisami wykonanymi już na miejscu markerem. Były umieszczane z boku i służyły raczej do użytku 
wewnętrznego, tak by można było się zorientować, kto powinien w danym momencie zagrać. Wywieszano je tylko na małych wydarzeniach, z liczbą uczestników nieprzekraczającą trzystu osób. Z racji kameralnego charakteru imprez, spora część uczestników znała się od dłuższego czasu i w razie potrzeby była $\mathrm{w}$ stanie znaleźć osobę odpowiedzialną w danym momencie za muzykę. Innym powodem wywieszenia tabliczki w widocznym miejscu było to, że osoby chcące zagrać mogły bez większych konsultacji i ustaleń wpisać się na niezarezerwowany do tej pory czas. Sam skorzystałem z tej szansy, żeby móc zagrać na jednym z opisywanych wydarzeń. Widać zatem, że przynajmniej, jeżeli chodzi o ekspozycję stołu mikserskiego i zaaranżowanie przestrzeni, wyniki uzyskane w trakcie obserwacji uczestniczącej pokrywają się z wnioskami uzyskanymi w toku badania ilościowego. Warunki i zasady panujące na scenach free tekno sprzyjają zacieraniu granic między DJ-ami a niegrającymi uczestnikami imprezy.

Inną rzeczą, na jaką zwróciłem uwagę $\mathrm{w}$ trakcie prowadzenia obserwacji była kwestia interakcji między tańczącymi uczestnikami a osobami grającymi. W trakcie badania ilościowego przyjąłem, że próby nawiązania interakcji mogą świadczyć o nadawaniu specjalnego statusu osobie DJ-a. Nie da się ukryć, że osoba grająca ma więcej okazji do interakcji z dotychczas nieznanymi osobami. Ważne jest jednak uwzględnienie charakteru takich kontaktów. We wszystkich trzech przypadkach, w których miałem okazję zagrać kontakty z innymi uczestnikami służyły raczej łamaniu barier niż ich budowaniu. Osoby obecne na wydarzeniach wchodziły za stół mikserski, spoglądały na płyty i sprzęt, dopytywały o tytuły utworów, częstowały alkoholem lub papierosami, „przybijały pięści”, obejmowały za ramię. W dwóch z trzech przypadków zdarzało się też, że imprezujący dokonywali drobnych korekcji na mikserze za pomocą gałek lub faderów. Interakcje inicjowane przez drugą stronę miały podobny charakter. Miałem okazję obserwować, jak inni DJ-e wychodzili na kilkanaście sekund zza stołu, prosząc kogoś z publiki na przykład o zapalniczkę lub stukając się butelką z piwem z osobami skaczącymi pod głośnikami. Osoby występujące, po skończonym graniu zwykle starały wmieszać się w tłum i rozpoczynały zabawę z ludźmi, którzy jeszcze przed chwilą tańczyli do prezentowanej lub wykonywanej przez nich muzyki. Sytuacje te przypominały więc nieco amerykańskie festiwale muzyki folk, na których artyści po skończonym występie schodzili porozmawiać z publiką [Frith 2011: 57-59].

Tak jak wspomniałem wcześniej, dla osoby z zewnątrz, przyzwyczajonej do dystansu między wykonawcą a publicznością, takie zachowanie może się wydawać „sztuczną naturalnością”. Wrażenie to ustępuje po bliższym 
poznaniu realiów free party lub dokonaniu prostych obliczeń. Największe z opisywanych tutaj wydarzeń przyciągnęło, według moich szacunków, nie więcej niż tysiąc osób [OU_13]. Ustawiono na nim cztery sceny, z których trzy działały od piątku wieczorem do niedzieli popołudniu. Czwarta działała jeszcze dzień dłużej, aż do poniedziałku. Zakładając, że trzy sceny działały po 40, a czwarta nawet do 70 godzin, otrzymujemy liczbę 190 godzin. Przeciętny set DJ-ski trwa 60 minut, choć zdarzają się oczywiście dłuższe. Jeśli każda $\mathrm{z}$ osób grających występowałaby łącznie dwie godziny, teknival potrzebowałby prawie 100 takich osób. Trudno oczekiwać, że w sytuacji, w której co dziesiąta osoba pełniła rolę DJ-a, będą one miały jakiś szczególny status.

\section{Podsumowanie}

Tezy o zacieraniu statusu między wykonawcami a publicznością w środowisku free tekno nie udało się sfalsyfikować. Można więc uznać, że zjawisko to rzeczywiście występuje. Świadczą o tym nie tylko filmy dokumentalne oraz artykuły prasowe (zarówno te pochodzące z mediów masowych, niszowych, jak i mikromediów), ale też analiza ilościowa zrealizowana dzięki materiałom zamieszczanym na portalu youtube.com oraz obserwacja uczestnicząca przeprowadzona w trakcie 13 różnych wydarzeń, na których działało 26 scen, z których tylko na pięciu nie grano muzyki związanej $\mathrm{z}$ free tekno.

Postulat Muggletona, aby badać nie tylko same praktyki, ale również znaczenia, jakie są im przepisywane przez uczestników uważam za słuszny [Muggleton 2004]. Jego spełnienie pozwala uniknąć zarzutów o nadinterpretację. Takie podejście nie może być jednak uważane za wyczerpujące. Uwzględnienie innych metod i technik badawczych, pozwala zgromadzić dane, które mogą posłużyć do weryfikacji obrazu prezentowanego przez uczestników badanej kultury. Jak zauważa Firth, antropologia społeczna powinna być „nauką sceptyczną”, a obowiązkiem badacza jest próba sprawdzenia prawdziwości tego, co mówią ludzie [por. Firth 2003: 21]. Zwłaszcza, że mamy prawo podejrzewać, że obraz może być nieco wyidealizowany, kiedy będą oni mówili o czymś dla nich ważnym. Uzupełnienie badania o wywiady z osobami zaangażowanymi w scenę free tekno, dostarczyłyby jeszcze silniejszych dowodów na to, że uczestnictwo we free party polega na partycypacji, współtworzeniu i zacieraniu różnic między organizatorami, performerami oraz resztą uczestników, zgodnie z ideologicznymi założe- 
niami sceny. Na typ etapie trudno jednak uznać, żeby podobny wniosek był zaledwie spekulacją lub nadinterpretacją badacza, który popełnił „błąd reifikacji” [Bourdieu i Wacqant 1992]. Opisywanie przynajmniej niektórych nurtów muzycznych wywodzących się bezpośredniego z ruchu rave jako „muzyki ludowej” nie jest zatem bezpodstawne.

$\mathrm{Na}$ koniec chciałbym jeszcze wrócić do wątku sygnalizowanego na początku tekstu, dotyczącego tezy stawianej między innymi przez Simona Fritha, który twierdził, że różnice między światami muzycznymi są mniejsze niż można by się tego spodziewać, znając wartości obecne w dyskursach dotyczących tychże światów. Jego argumentacja opierała się na tym, że niezależnie od ideologii, organizatorzy, artyści i uczestnicy stają przed podobnymi problemami związanymi chociażby z podziałem zadań, praktycznymi problemami dotyczącymi organizacji imprez czy dystrybucji muzyki. Upraszczając, można by powiedzieć, że materialna baza jest dla wszystkich mniej więcej podobna, a to wymusza podobne sposoby działania, niezależnie od dominującej na scenie ideologii [Frith 2011: 46-61].

Zgadzam się z Frithem w tym, że realia, w jakich muszą funkcjonować osoby związane $z$ daną sceną muzyczną, ograniczają możliwości realizacji pewnych postulatów ideologicznych. Moim zdaniem jednak, autor ten zbyt szybko założył, że realia te są zwykle bardzo do siebie podobne. Przypadek sceny free tekno, pokazuje, że istnieją światy muzyczne, w których poszukuje się albo wręcz aktywnie tworzy alternatywne warunki dla funkcjonowania sceny. Gromadzenie własnego sprzętu muzycznego pozwala na anektowanie pustych przestrzeni w lasach lub opuszczonych budynkach, a to $\mathrm{z}$ kolei pozwala na dużą swobodę $\mathrm{w}$ aranżacji przestrzeni. Zwyczaj grania bez przerwy, przy jednoczesnym ograniczaniu dopływu nowych uczestników imprez przez ostrożne dzielenie się informacjami i organizację wydarzeń w miejscach trudno dostępnych, skutkuje tym, że spory procent uczestników zawsze stanowią osoby grające lub tworzące swoją własną muzykę. Rezygnacja z gratyfikacji finansowej wśród performerów obniża koszty organizacji, co ułatwia zachowanie niezależności finansowej i ogranicza wpływ mechanizmów rynkowych. Przeciwdziała to też pełnej profesjonalizacji wśród twórców, którzy dzięki temu zachowują postawę pasjonata raczej niż zawodowca, bliską także nietwórcom. Wniosek Muggletona należałoby więc uzupełnić o to, że wspomniane przez niego upodabnianie się do siebie rozmaitych światów muzycznych jest nieuniknione o tyle, o ile podobna jest ich materialna baza. Ta zaś nie zawsze musi być taka sama. 


\section{Bibliografia}

Banks M. (2009), Badania wizualne w badaniach jakościowych, Warszawa.

Bourdieu P. (2007), Reguty sztuki. Geneza i struktura pola literackiego, Kraków.

Bourdieu P., Wacqant L.J.D. (1992), An Invitation to Reflexive Sociology, Cambridge.

Collin M. (2006), Odmienny stan świadomości. Historia kultury ecstasy i acid house, Warszawa.

Cybulski M. (2011), Europejska tradycja soundsystemowa, http://sic.szczecin.pl/?s=artykuly\&id=370, [01.08.2017].

Fatyga B. (2005), Dzicy z naszej ulicy. Antropologia kultury młodzieżowej, Warszawa.

Firth S. (2011), Sceniczne rytuały. O wartości muzyki popularnej, Kraków.

Frith R. (2003), Czy antropologia społeczna ma przyszłość?, [w:] M. Kępny, E. Nowicka (red.), Badanie kultury. Elementy teorii antropologicznej, Warszawa.

Fukuyama F. (2009), Koniec historii i ostatni człowiek, Kraków.

Goffman E. (2009), Człowiek $w$ teatrze życia codziennego, Warszawa.

Hebdige D. (1979), Subculture: The meaning of style, Londyn.

Imbierowicz S. (1996), Sampling, „Machina”, nr 7.

Jabłońska B. (2014), Socjologia muzyki, Warszawa.

Konecki K. (2000), Studia z metodologii badań jakościowych, Warszawa.

Leszczyński R. (1996), Coraz więcej rytmu, „Gazeta Wyborcza. Magazyn”, nr 10.

Marshall J. (1996), Zippisi, „Playboy”, nr 2.

Muggleton D. (2004), Wewnątrz subkultury. Ponowoczesne znaczenie stylu, Kraków.

Nieżytboy (2013), Punk zapisany w kodzie binarnym, „Chaos w Mojej Głowie”, nr 9.

Nowak J. (2010), Metodologiczne rozterki współczesnych antropologów: obserwacja uczestniczaca w praktyce, „Studia Socjologiczne”, nr 4.

Partridge C. (2010), Dub in Babylon. Understanding the Evolution and Significance of Dub Reggae in Jamaica and Britain from King Tubby to Post-punk, Londyn.

Peach M. (1997), Emancypacja szumów. Czym jest muzyka techno? „Tygodnik Powszechny", nr 3.

Podgórska J. (1997), Techno obrzęd, „Polityka”, nr 1.

Popper K. (1977), Logika odkrycia naukowego, Warszawa.

Sarnowicz E. (1996), Piękno instalacji elektrycznych, „Gazeta Wyborcza. Magazyn”, nr 10.

Smuga J. (1996), Kultura techno, „Machina”, nr 4-5.

Socha Z. (2011), Między bytem a niebytem. Socjologia muzyki w Polsce, „Muzyka”, nr 4.

Sokalla K. (2016), Polskie rave'y w rytmie tekno, „Gazeta Magnetofonowa”, nr 2.

Stockfelt O. (2010), Odpowiednie sposoby stuchania, (w:) Ch. Cox, D. Warner (red.), Kultura dźwięku. Teksty o muzyce nowoczesnej, Gdańsk.

Strauss A. (1978), A Social World Perspective, [w:] N.K. Denzin (red.), Studies in Symbolic Interaction, t. 1, Greenwich. 
Strauss A. (1982), Social Worlds and They Segmentation Processes, [w:] N.K. Denzin (red.), Studies in Symbolic Interaction, t. 5, Greenwich.

Szlendak T. (1997), Techno-dzieci ery industrialnej, „Studia Socjologiczne”, nr 1.

Szlendak T. (1998), Technomania. Cyberplemię w zwierciadle socjologii, Toruń.

Thornton S. (2013), Club Cultures. Music, Media and Subcultural Capital, Cambridge

Wojtowicz A. (1996), Moda techno, „Machina”, nr 4-5.

Wróblewski M. (red.), (2012), Kultura i hegemonia. Antologia tekstów szkoły z Birmingham, Poznań.

\section{Filmografia}

23 Minute Warning - Spiral Tribe - World Traveller Adventures (1994), Damien Raclot, Krystof Gillier.

Babylon (1980), Martin Stellmann, Franco Rosso.

Dub Stories (2006), David Katz.

Dub Echoes (2008), David Katz.

Freetekno (2011), Gunnar Hauth.

Heretic. We Had a Dream (2010), Damien Raclot-Dauliac.

Il respiro del mostro (2011), Andrea Zambelli.

Notes on Breakcore (2006), David Kleinl.

Psychedelic Zion (2000), Isri Halpern.

\section{Strony internetowe}

audioriver.pl, [31.07.2017].

legislation.gov.uk/ukpga/1994/33/contents, [30.07.2017].

slaskie.naszemiasto.pl/artykul/relacja-tak-bylo-na-mayday-2015-w-katowickim-spodkuzdjecia,3564602,artgal,t,id,tm.html, [31.07.2017].

sunrisefestival.pl/info-o-festiwalu, [31.07.2017].

techno.org/electronic-music-guide, [30.07.2017].

youtube.com/watch?v=_khPdMzjpAA, [01.08.2017].

youtube.com/watch?v=hlupGH8aLXU, [28.07.2017].

youtube.com/watch?v=x_t43XJC9Xs, [31.07.2017]. 


\section{SUMMARY}

\section{In the Shadow, or on the Pedestal? DJ in the "Free Tekno" Culture, and the Discourse of "Folk" Music}

Blurring of the distinction between performers and audience is one of the characteristics of musical worlds dominated by "folk" music discourse. The rave movement originated in the United Kingdom in the late 1980s and early 1990s, and was described as "new folk music" due to the practice of collective dance, and the ideology of equality. Tomasz Szlendak's research on the phenomenon of "technomania", which was conducted in the 1990s, shows that these ideological postulates were not always implemented. The form and the course of a "technoparty" were often influenced by the music club's rules and regulations. The so-called "free tekno" is a contemporary music scene that operates outside the club context and originates in the early rave. A quantitative analysis of one hundred videos on the youtube.com website, and a participant observation carried out between 2013 and 2017 at 13 "free tekno" events in Poland suggests that outside the clubs, the ideological postulates of the "folk" musical discourse are realised to a greater extent than at "technoparites" described by Szlendak.

KEYWORDS: anthropology of music, free tekno, participant observation, sociology of music, visual sociology 